\title{
Sikap Perawat terhadap Persiapan Kematian pada Pasien Kanker Stadium Lanjut
}

\author{
Nurul Izah ${ }^{1}$, Fitria Handayani ${ }^{2}$, Henni Kusuma ${ }^{3}$

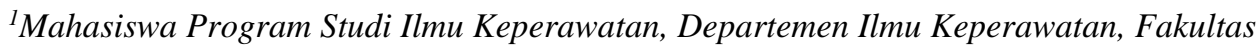 \\ Kedokteran, Universitas Diponegoro, Semarang, Indonesia, email: izazahnrl@yahoo.co.id) \\ ${ }^{2}$ Dosen Keperawatan Dewasa, Departemen Ilmu Keperawatan, Fakultas Kedokteran, Universitas \\ Diponegoro, Semarang, Indonesia, email: fitria.handayani@fk.undip.ac.id) \\ ${ }^{3}$ Dosen Keperawatan Dewasa, Departemen Ilmu Keperawatan, Fakultas Kedokteran, Universitas \\ Diponegoro, Semarang, Indonesia, email: henni.kusuma@fk.undip.ac.id) \\ Corresponding Author: fitria.handayani @ fk.undip.ac.id
}

\begin{abstract}
Abstrak
Pasien kanker stadium lanjut atau tahap terminal secara umum mengalami kesulitan dalam penyembuhannya dan berakhir dengan kematian. Peran perawat sangat diperlukan dalam mempersiapkan kematian yang damai bagi pasien dengan kondisi ini dan keluarganya melalui perawatan menjelang ajal (end-of-life care). Sudut pandang terhadap kesiapan perawat dalam merawat pasien menjelang ajal dapat dijelaskan melalui sikapnya. Sikap perawat dapat mempengaruhi emosi dan perilaku perawat dalam merawat pasien terminal dan keluarganya. Penelitian ini bertujuan untuk mendeskripsikan sikap perawat terhadap persiapan kematian pada pasien kanker stadium lanjut. Jenis penelitian ini adalah kuantitatif noneksperimental deskriptif survei. Teknik pengambilan sampel yang digunakan dalam penelitian ini adalah total sampling dengan jumlah sampel sebanyak 145 orang responden. Data penelitian ini dikumpulkan menggunakan kuesioner The Frommelt Attitude Toward Care of the Dying Scale (FATCOD). Hasil penelitian ini menunjukkan 76 orang dari 145 perawat $(52,4 \%)$ memiliki sikap positif terhadap persiapan kematian yang damai bagi pasien kanker stadium lanjut. Hasil analisis lebih lanjut menunjukkan kedua domain sikap perawat mayoritas positif yakni $53,8 \%$ perawat memiliki sikap positif terhadap persiapan kematian bagi pasien kanker tahap terminal dan $57,2 \%$ perawat memiliki sikap positif terhadap persiapan keluarga menghadapi kematian pasien kanker stadium lanjut. Intervensi keperawatan bagi pasien kanker stadium lanjut menjelang ajal dan keluarga perlu ditingkatkan. Sangat penting untuk perawat berkomunikasi dengan pasien dan keluarga mereka dalam membahas tentang masalah akhir kehidupan untuk meningkatkan kualitas hidupnya dan mempersiapkan kematian yang damai serta berkualitas.
\end{abstract}

Kata kunci : kanker tahap terminal, perawatan menjelang ajal, sikap perawat 


\begin{abstract}
Patients with advanced cancer are generally difficult to be healed and end up in death. Nurses' roles are needed in preparing the patient's death through end-of-life care. The nurses' viewpoint of readiness in caring for a dying patient can be explained through their attitudes. Nurses' attitudes will affect the nurses' emotions and actions while conducting end-of-life care for dying patients and their families. This study aims to determine the nurses' attitudes toward death preparation in advanced cancer patients at RSUP Dr. Kariadi Semarang. The type of this research is descriptive quantitative non-experimental. The sampling technique used was total sampling with a sample of 145 respondents. Data was collected by using The Frommelt Attitude Toward Care of the Dying Scale (FATCOD) questionnaire. The results showed 76 of 145 nurses $(52.4 \%)$ had positive attitudes toward death preparation. The result of the analysis of two domains showed $53.8 \%$ of nurses had positive attitudes toward death preparation in advanced cancer patients and also $57.2 \%$ of nurses had positive attitudes toward death preparation in families of advanced cancer patients. Nurse interventions are still needed to improve communication with patients and their families in discussing about end-of-life issues for improving the quality of life and good death.
\end{abstract}

Keywords: advanced cancer, death preparation, nurses' attitudes

\title{
PENDAHULUAN
}

Penyakit kanker menjadi salah satu dari sepuluh penyebab kematian utama di seluruh dunia. Kanker menempati peringkat kedua dari kematian global. Jumlah kasus kanker di seluruh dunia pada tahun 2018 mencapai 18,1 juta dan 9,6 juta diantaranya mengalami kematian (The International Agency for Research on Cancer, 2018). Di Indonesia pada tahun 2018 angka kejadian kanker meningkat dari 1,4\% menjadi 1,8\% kasus. Propinsi Jawa Tengah merupakan provinsi dengan penderita kanker terbanyak yaitu sekitar 68.638 jiwa (Kementrian Kesehatan Republik Indonesia, 2018). Besaran masalah kanker dapat dilihat dari pasien kanker yang datang untuk pengobatan, dimana $60-70 \%$ penderita sudah dalam stadium IIIIV atau terminal (Depkes RI, 2016).

Pasien dengan kanker stadium lanjut atau terminal memungkinkan kesembuhan sulit diperoleh. Prognosis penyakit ini biasanya buruk dan dapat berakhir dengan kematian (Perry \& Potter, 2010). Kematian merupakan ancaman yang menakutkan bagi pasien dengan kondisi terminal. Sehingga peran perawat sangat penting dalam membantu pasien dan keluarga dalam mempersiapkan 
kematian melalui perawatan akhir kehidupan. Persiapan kematian diharapkan dapat memberikan kondisi kematian yang baik pada pasien serta keluarga.

Kematian yang baik merupakan tujuan dari pemberian perawatan akhir kehidupan. Kematian yang baik memiliki beberapa kriteria diantaranya pasien mengetahui kapan kematian diperkirakan akan datang. Pasien dapat mengendalikan diri dari situasi yang terjadi akibat penyakit yang di deritanya. Pasien dapat mengontrol atau bahkan terbebas dari nyeri serta tanda dan gejala penyakitnya melalui pain management yang diberikan. Pasien mendapatkan informasi dari petugas kesehatan baik dokter maupun perawat terkait dengan diagnosis dan prognosis penyakitnya. Pasien berhak memilih atas tempat yang diinginkan untuk meninggal seperti di rumah atau rumah sakit (Tayeb, Al-Zamel, Fareed, \& Abouellail, 2010; Miyashita, et al., 2015).

Pasien mendapatkan dukungan spiritual maupun emosional yang dibutuhkan baik dari perawat maupun keluarga. Pasien berhak memilih atas siapa saja yang pasien inginkan untuk menemani pasien saat menjelang kematian pasien. Pasien memiliki kesempatan untuk berpamitan mengucapkan salam perpisahan kepada teman maupun anggota keluarganya. Pasien memiliki rasa dihormati atas segala keputusan yang telah dibuat. Pasien berkontribusi aktif hingga akhir kehidupannya dan juga dapat menyelesaikan tugas maupun harapannya sehingga pasien dapat meninggal dengan bermartabat. Kriteria-kriteria tersebut merupakan kriteria dari kematian yang baik (Tayeb, et al., 2010; Miyashita, et al., 2015). Guna mempersiapkan kematian yang baik serta meningkatkan kualitas hidup pasien, dibutuhkan perawatan yang disebut perawatan akhir kehidupan.

Perawatan akhir kehidupan atau menjelang kematian merupakan perawatan yang sangat dibutuhkan oleh pasien kanker stadium lanjut (Wahyuni, Huda, \& Utami, 2015). Perawatan akhir kehidupan adalah pelayanan terintegrasi yang berfokus pada peningkatan kualitas hidup pasien dan keluarga dalam menghadapi penyakit yang mengancam kehidupan (Departemen Kesehatan RI, 2007). Tujuan utamanya berupa peningkatkan kualitas hidup pasien maupun keluarga dan mempersiapkan kematian yang baik. Persiapan menjelang kematian diberikan pada pasien dengan kondisi penyakit terminal yang memiliki waktu enam bulan atau 
kurang untuk hidup. Persiapan ini dilakukan agar pasien dapat memahami penyakit yang dideritanya serta membantu pasien hingga berada dalam tahap penerimaan kenyataan bahwa dirinya akan meninggal (Vergo, et al., 2016).

Peran perawat sangat dibutuhkan terhadap persiapan kematian pasien melalui dukungan psikologi, spiritual, fisik, dan sosial (Kübler-Ross, 2009). Peran perawat dalam memberikan dukungan psikologi seperti membantu pasien dalam mengendalikan perasaan negatif dan meningkatkan perasaan positif selama proses menuju kematian. Pasien juga dibantu untuk mempertahankan kepuasan terhadap kemampuan dan mempersiapkan diri menuju kematian. Perawat juga membantu menyelesaikan permasalah sosial seperti membantu pasien mengucapkan maaf, berpamitan, dan juga memelihara hubungan baik antara pasien dengan keluarga maupun teman-temannya. Dukungan fisik dapat berupa membantu pasien dalam menghadapi gejala-gejala atau ketidakmampuan akibat penyakit. Pemberian dukungan spiritualitas dengan membimbing pasien dalam berdoa maupun menghadirkan pemuka agama (Atika, Fitriyah, \& Indriani, 2008). Hal tersebut didukung oleh penelitian yang menyatakan bahwa perawatan paliatif sangat berperan untuk meningkatkan kualitas hidup dan mengurangi sakit ataupun mempersiapkan kematian pasien kanker stadium IV melalui pendekatan dukungan psikologi, spiritual, fisik, dan sosial (Hasheesh, Abozeid, El-Said, \& Alhujaili, 2013).

Pandangan perawat terhadap kepedulian dalam merawat pasien yang akan meninggal dapat dijelaskan melalui sikapnya. Sikap dibentuk sebagai hasil dari evaluasi terhadap pembelajaran yang dianggap setuju dan tidak dan dapat berubah seiring dengan bertambahnya pengalaman dan kemampuan. Sikap perawat terhadap persiapan kematian pasien kanker stadium lanjut merupakan respon dari kesiapan atau kesediaan dalam mengekspresikan hasil pembelajaran melalui perawatan akhir kehidupan. Sikap perawat akan mempengaruhi emosi dan tindakan dari perawat dalam melakukan perawatan pada pasien yang akan menuju kematian (Hasheesh, et al., 2013).

Penelitian terdahulu mengungkapkan bahwa perawat merasakan ketidakmampuan dan mengalami tekanan yang berat dalam memberikan perawatan 
pada pasien menjelang kematian. Kematian yang mendadak membuat perawat belum optimal memberikan perawatan persiapan kematian kepada pasien dan keluarga. Perawat juga melaporkan bahwa merasa tidak puas dalam memberikan dukungan kepada pasien dan keluarga terhadap persiapan kematian pasien. Bahkan terdapat juga perawat yang menghindari bertemu dengan keluarga dan pasien ketika menjelang kematiannya (Mak, Chung, Chiang, \& Chui, 2013). Penelitian lain tentang sikap dilakukan pada mahasiswa keperawatan menunjukkan bahwa sikap mahasiswa dalam merawat pasien menjelang kematian masih tergolong dalam kategori rendah. Sikap mahasiswa keperawatan yang tergolong rendah dipengaruhi oleh pengalaman mahasiswa yang masih minimum dalam merawat pasien menjelang kematian secara langsung (A'la, Setioputro, \& Kurniawan, 2018).

Kematian yang masih dianggap tabu menjadi problematika bagi perawat. Adanya kesulitan komunikasi yang efektif tentang perihal persiapan kematian menjadi hambatan perawat untuk berinteraksi dengan keluarga maupun pasien. Perawat juga dapat mengalami tekanan emosional ketika merawat pasien menjelang kematian. Di sisi lain, pengalaman ini akan membantu perawat dalam merefleksikan makna kematian dan kehidupan dengan pasien. Hal ini secara positif akan mempengaruhi kehidupan sehari-hari perawat dengan pasien, sikap, maupun perilaku terhadap kepedulian dalam merawat pasien menjelang kematian. Perawat memiliki kemauan yang kuat dalam memberikan perawatan pasien di akhir kehidupan yang berkualitas baik kepada pasien maupun keluarga namun perawat mengalami tekanan moral karena keterbatasan diri, serta kurangnya pengetahuan dan pengalaman dalam merawat pasien menjelang kematian (Zheng, Guo, Dong, \& Owens, 2015). Penelitian sebelumnya di Indonesia terkait dengan sikap perawat menunjukkan 21 dari 50 perawat (42\%) masih memiliki sikap yang kurang baik terhadap perawatan pasien menjelang ajal (Fitri, Natosba, \& Andhini, 2017). Penelitian yang telah dilakukan tersebut belum menggambarkan sikap perawat terhadap persiapan kematian pada pasien dan keluarga. Oleh karena itu, penelitian ini bertujuan untuk menganalisa sikap perawat terhadap persiapan kematian pada pasien dan keluarga pasien kanker stadium lanjut. 


\section{METODE PENELITIAN}

Penelitian ini merupakan penelitian kuantitatif dengan metode deskriptif survei. Teknik pengambilan sampel menggunakan total sampling yaitu 145 perawat. Kriteria inklusi dari penelitian ini yaitu semua perawat yang bekerja di ruang onkologi. Kriteria eksklusi dari penelitian ini yaitu perawat yang sedang cuti. Pengambilan data dilakukan pada bulan April 2019 di salah satu RS wilayah Jawa Tengah. Responden diberikan penjelasan terkait dengan manfaat dan hak-hak sebagai responden. Setelah itu, responden yang menyetujui untuk menjadi responden dalam penelitian ini menandatangani lembar informed consent. Penelitian ini menggunakan analisis univariat yang menggambarkan distribusi frekuensi.

Instrumen yang digunakan untuk mengukur sikap perawat dalam mempersiapkan kematian yaitu kuesioner The Frommelt Attitude Toward Care of the Dying Scale (FATCOD) yang telah diadopsi dalam Bahasa Indonesia. Kuesioner ini terdiri dari dua sub-scale yaitu sikap perawat terhadap pasien dan sikap perawat terhadap keluarga pasien. Pernyataan yang berkaitan dengan sikap perawat terhadap persiapan kematian pada pasien berjumlah 20 pernyataan sedangkan sikap perawat terhadap persiapan kematian pada keluarga berjumlah 10 pernyataan. Kuesioner telah teruji valid menggunakan Uji Korelasi Pearson dengan nilai rentang -0,278 sampai dengan 0,544 sehingga semua item dinyatakan valid. Kuesioner juga telah dilakukan uji reliabilitas menggunakan koefisien Alfa Cronbach dengan nilai 0,680 sehingga kuesioner dinyatakan reliabel (A'la, 2016). Penelitian ini telah lulus uji etik dari komite etik KEPK RSUP Dr. Kariadi Semarang dengan No.114/EC/KEPK-RSDK/2019. 


\section{HASIL DAN PEMBAHASAN}

\section{A. Hasil Penelitian}

1. Karakteristik Responden

Tabel 1. Data Tendensi Sentral Usia Responden pada April $2019(\mathrm{n}=145)$

\begin{tabular}{lcccc}
\hline Karakteristik Responden & Mean & Median & Minimum & Maksimum \\
\hline Usia & 32,21 & 30 & 22 & 58 \\
\hline
\end{tabular}

Tabel 1 menunjukkan hasil bahwa responden memiliki rentang usia mulai dari 22 sampai dengan 58 tahun dengan rata-rata usia responden ialah 32 tahun.

Tabel 2. Distribusi Frekuensi Responden berdasarkan Jenis Kelamin, Pendidikan, Lama Bekerja di Unit Pelayanan Kanker, dan Keikutsertaan dalam Seminar/ Pelatihan Perawatan Paliatif pada April $2019(n=145)$

\begin{tabular}{lcc}
\hline Karakteristik Responden & Frekuensi (n) & Persentase (\%) \\
\hline Jenis Kelamin & & \\
$\quad$ Laki-Laki & 61 & 42,1 \\
Perempuan & 84 & 57,9 \\
Pendidikan & & \\
$\quad$ DIII Keperawatan & 94 & 64,8 \\
$\quad$ Ners & 51 & 35,2 \\
Lama Bekerja di Unit Pelayanan Kanker & & \\
0-5 tahun & 115 & 79,3 \\
6-10 tahun & 22 & 15,2 \\
11-15 tahun & 4 & 2,8 \\
16-20 tahun & 3 & 2,1 \\
>20 tahun & 1 & 0,7 \\
Keikutsertaan dalam Seminar/Pelatihan & & \\
Perawatan Paliatif & & 43,4 \\
$\quad$ Tidak Pernah & 63 & 56,6 \\
Pernah & 82 & 100 \\
\hline Total & 145 & \\
\hline
\end{tabular}

Tabel 2 menunjukkan hasil lebih dari separuh responden berjenis kelamin perempuan yakni 84 orang $(57,9 \%)$, mayoritas responden berpendidikan terakhir DIII Keperawatan meliputi 94 orang $(64,8 \%)$, sebagian besar responden telah bekerja di unit pelayanan kanker selama 0-5 tahun sebanyak 115 orang (79,3\%), dan sejumlah 82 responden $(56,6 \%)$ pernah mengikuti seminar atau pelatihan tentang perawatan paliatif. 
2. Sikap Perawat terhadap Persiapan Kematian

Tabel 3. Distribusi Frekuensi Sikap Perawat terhadap Persiapan Kematian pada Pasien Kanker Stadium Lanjut ( $\mathrm{n}=145)$

\begin{tabular}{lcc}
\hline Sikap & Frekuensi (n) & Persentase (\%) \\
\hline Positif & 76 & 52,4 \\
Negatif & 69 & 47,6 \\
\hline Total & 145 & 100 \\
\hline
\end{tabular}

Tabel 3 menunjukkan bahwa lebih dari setengah jumlah total perawat $(52,4 \%)$ memiliki sikap yang positif terhadap persiapan kematian pasien kanker tahap terminal.

Tabel 4. Distribusi Frekuensi Domain Sikap Perawat terhadap Persiapan Kematian pada Pasien Kanker Stadium Lanjut ( $n=145)$

\begin{tabular}{llcc}
\hline Domain Sikap & Kategori & $\begin{array}{c}\text { Frekuensi } \\
\text { (n) }\end{array}$ & $\begin{array}{c}\text { Persentase } \\
(\boldsymbol{\%})\end{array}$ \\
\hline Persiapan Kematian pada & Positif & 78 & 53,8 \\
Pasien & Negatif & 67 & 46,2 \\
Persiapan Kematian pada & Positif & 83 & 57,2 \\
Keluarga & Negatif & 62 & 42,8 \\
\hline Total & & 145 & 100 \\
\hline
\end{tabular}

Tabel 4 menunjukkan bahwa mayoritas responden memiliki sikap yang positif pada seluruh domain sikap perawat terhadap persiapan kematian pada pasien kanker stadium lanjut. Sebanyak $78(53,8 \%)$ perawat memiliki sikap yang positif terhadap persiapan kematian pada pasien dan juga sebanyak $83(57,2 \%)$ perawat memiliki sikap yang positif terhadap persiapan kematian pada keluarga pasien.

Tabel 5. Distribusi Frekuensi Jawaban Pernyataan tentang Domain Sikap Perawat terhadap Persiapan Kematian pada Pasien Kanker Stadium Lanjut $(n=145)$

\begin{tabular}{|c|c|c|c|c|c|c|}
\hline $\begin{array}{l}\text { No. } \\
\text { Item }\end{array}$ & $\begin{array}{lr}\begin{array}{l}\text { Domain } \\
\text { terhadap }\end{array} & \begin{array}{r}\text { Perawat } \\
\text { Persiapan }\end{array} \\
\text { Kematian } & \text { pada } \\
\text { Pasien }\end{array}$ & $\begin{array}{l}\text { Sangat } \\
\text { Setuju }\end{array}$ & Setuju & $\begin{array}{c}\text { Ragu- } \\
\text { Ragu }\end{array}$ & $\begin{array}{c}\text { Tidak } \\
\text { Setuju }\end{array}$ & $\begin{array}{l}\text { Sangat } \\
\text { Tidak } \\
\text { Setuju }\end{array}$ \\
\hline P1 & $\begin{array}{lr}\text { Memberikan } & \text { perawatan } \\
\text { menjelang ajal adalah } \\
\text { pengalaman berharga }\end{array}$ & $\begin{array}{c}49 \\
(33,8 \%)\end{array}$ & $\begin{array}{c}93 \\
(64,1 \%)\end{array}$ & $\begin{array}{c}0 \\
(0 \%)\end{array}$ & $\begin{array}{c}3 \\
(2,1 \%)\end{array}$ & $\begin{array}{c}0 \\
(0 \%)\end{array}$ \\
\hline $\mathrm{P} 2$ & $\begin{array}{l}\text { Kematian bukanlah hal } \\
\text { terburuk yang dapat terjadi } \\
\text { pada individu }\end{array}$ & $\begin{array}{c}23 \\
(15,9 \%)\end{array}$ & $\begin{array}{c}82 \\
(56,6 \%)\end{array}$ & $\begin{array}{c}10 \\
(6,9 \%)\end{array}$ & $\begin{array}{c}26 \\
(17,9 \%)\end{array}$ & $\begin{array}{c}4 \\
(2,8 \%)\end{array}$ \\
\hline
\end{tabular}




\begin{tabular}{|c|c|c|c|c|c|c|}
\hline $\begin{array}{l}\text { No. } \\
\text { Item }\end{array}$ & $\begin{array}{l}\begin{array}{l}\text { Domain } \\
\text { Sikap }\end{array} \begin{array}{r}\text { Perawat } \\
\text { Persiapan }\end{array} \\
\text { Kematian }\end{array}$ & $\begin{array}{l}\text { Sangat } \\
\text { Setuju }\end{array}$ & Setuju & $\begin{array}{l}\text { Ragu- } \\
\text { Ragu }\end{array}$ & $\begin{array}{c}\text { Tidak } \\
\text { Setuju }\end{array}$ & $\begin{array}{c}\text { Sangat } \\
\text { Tidak } \\
\text { Setuju }\end{array}$ \\
\hline P3 & $\begin{array}{l}\text { Saya akan merasa tidak } \\
\text { nyaman ketika membicarakan } \\
\text { kematian dengan pasien yang } \\
\text { menjelang ajal }\end{array}$ & $\begin{array}{c}20 \\
(13,8 \%)\end{array}$ & $\begin{array}{c}58 \\
(40,0 \%)\end{array}$ & $\begin{array}{c}20 \\
(13,8 \%)\end{array}$ & $\begin{array}{c}42 \\
(29,0 \%)\end{array}$ & $\begin{array}{c}5 \\
(3,4 \%)\end{array}$ \\
\hline P5 & $\begin{array}{l}\text { Saya tidak ingin merawat } \\
\text { pasien yang mendekati ajal }\end{array}$ & $\begin{array}{c}2 \\
(1,4 \%)\end{array}$ & $\begin{array}{c}3 \\
(2,1 \%)\end{array}$ & $\begin{array}{c}2 \\
(1,4 \%)\end{array}$ & $\begin{array}{c}67 \\
(46,2 \%)\end{array}$ & $\begin{array}{c}71 \\
(49,0 \%)\end{array}$ \\
\hline P6 & $\begin{array}{l}\text { Perawat tidak perlu untuk } \\
\text { membicarakan terkait kematian } \\
\text { bersama pasien yang } \\
\text { menjelang ajal }\end{array}$ & $\begin{array}{c}7 \\
(4,8 \%)\end{array}$ & $\begin{array}{c}37 \\
(25,5 \%)\end{array}$ & $\begin{array}{c}23 \\
(15,9 \%)\end{array}$ & $\begin{array}{c}65 \\
(44,8 \%)\end{array}$ & $\begin{array}{c}13 \\
(9,0 \%)\end{array}$ \\
\hline P7 & $\begin{array}{l}\text { Waktu yang lama dalam } \\
\text { perawatan pasien menjelang } \\
\text { ajal dapat membuat saya } \\
\text { frustrasi }\end{array}$ & $\begin{array}{c}2 \\
(1,4 \%)\end{array}$ & $\begin{array}{c}7 \\
(4,8 \%)\end{array}$ & $\begin{array}{c}7 \\
(4,8 \%)\end{array}$ & $\begin{array}{c}96 \\
(66,2 \%)\end{array}$ & $\begin{array}{c}33 \\
(22,8 \%)\end{array}$ \\
\hline P8 & $\begin{array}{l}\text { Saya akan menjadi sedih ketika } \\
\text { pasien menjelang ajal yang } \\
\text { saya rawat menyerah dalam } \\
\text { mendapatkan harapan yang } \\
\text { lebih baik }\end{array}$ & $\begin{array}{c}16 \\
(11,0 \%)\end{array}$ & $\begin{array}{c}99 \\
(68,3 \%)\end{array}$ & $\begin{array}{c}9 \\
(6,2 \%)\end{array}$ & $\begin{array}{c}15 \\
(10,3 \%)\end{array}$ & $\begin{array}{c}6 \\
(4,1 \%)\end{array}$ \\
\hline P10 & $\begin{array}{l}\text { Pasien yang menjelang ajal } \\
\text { membutuhkan waktu menuju } \\
\text { kematian }\end{array}$ & $\begin{array}{c}18 \\
(12,4 \%)\end{array}$ & $\begin{array}{c}94 \\
(64,8 \%)\end{array}$ & $\begin{array}{c}27 \\
(18,6 \%)\end{array}$ & $\begin{array}{c}6 \\
(4,1 \%)\end{array}$ & $\begin{array}{c}0 \\
(0 \%)\end{array}$ \\
\hline P11 & $\begin{array}{l}\text { Ketika pasien bertanya "apakah } \\
\text { saya akan meninggal?" saya } \\
\text { berpikir mengalihkan } \\
\text { pembicaraan menuju hal yang } \\
\text { menyenangkan adalah pilihan } \\
\text { terbaik }\end{array}$ & $\begin{array}{c}13 \\
(9,0 \%)\end{array}$ & $\begin{array}{c}82 \\
(56,6 \%)\end{array}$ & $\begin{array}{c}21 \\
(14,5 \%)\end{array}$ & $\begin{array}{c}26 \\
(17,9 \%)\end{array}$ & $\begin{array}{c}3 \\
(2,1 \%)\end{array}$ \\
\hline P13 & $\begin{array}{l}\text { Saya berharap pasien yang saya } \\
\text { rawat meninggal saat saya tidak } \\
\text { ada disampingnya }\end{array}$ & $\begin{array}{c}1 \\
(0,7 \%)\end{array}$ & $\begin{array}{c}12 \\
(8,3 \%)\end{array}$ & $\begin{array}{c}27 \\
(18,6 \%)\end{array}$ & $\begin{array}{c}91 \\
(62,8 \%)\end{array}$ & $\begin{array}{c}14 \\
(9,7 \%)\end{array}$ \\
\hline $\mathrm{P} 14$ & $\begin{array}{l}\text { Saya takut menemani pasien } \\
\text { menjelang ajal }\end{array}$ & $\begin{array}{c}0 \\
(0 \%)\end{array}$ & $\begin{array}{c}8 \\
(5,5 \%)\end{array}$ & $\begin{array}{c}4 \\
(2,8 \%)\end{array}$ & $\begin{array}{c}91 \\
(62,8 \%)\end{array}$ & $\begin{array}{c}42 \\
(29,0 \%)\end{array}$ \\
\hline P15 & $\begin{array}{l}\text { Ketika pasien telah meninggal, } \\
\text { saya merasa seperti lari dari } \\
\text { permasalahan }\end{array}$ & $\begin{array}{c}2 \\
(1,4 \%)\end{array}$ & $\begin{array}{c}7 \\
(4,8 \%)\end{array}$ & $\begin{array}{c}7 \\
(4,8 \%)\end{array}$ & $\begin{array}{c}96 \\
(66,2 \%)\end{array}$ & $\begin{array}{c}33 \\
(22,8 \%)\end{array}$ \\
\hline P17 & $\begin{array}{l}\text { Perawat seharusnya keluar dari } \\
\text { keterlibatannya dari pasien, } \\
\text { saat pasien dekat dengan } \\
\text { kematian }\end{array}$ & $\begin{array}{c}5 \\
(3,4 \%)\end{array}$ & $\begin{array}{c}8 \\
(5,5 \%)\end{array}$ & $\begin{array}{c}6 \\
(4,1 \%)\end{array}$ & $\begin{array}{c}91 \\
(62,8 \%)\end{array}$ & $\begin{array}{c}35 \\
(24,1 \%)\end{array}$ \\
\hline P19 & $\begin{array}{l}\text { Pasien menjelang ajal tidak } \\
\text { perlu terlibat dalam pembuatan } \\
\text { keputusan perawatan yang dia } \\
\text { dapatkan }\end{array}$ & $\begin{array}{c}5 \\
(3,4 \%)\end{array}$ & $\begin{array}{c}23 \\
(15,9 \%)\end{array}$ & $\begin{array}{c}11 \\
(7,6 \%)\end{array}$ & $\begin{array}{c}85 \\
(58,6 \%)\end{array}$ & $\begin{array}{c}21 \\
(14,5 \%)\end{array}$ \\
\hline
\end{tabular}




\begin{tabular}{|c|c|c|c|c|c|c|}
\hline $\begin{array}{l}\text { No. } \\
\text { Item }\end{array}$ & $\begin{array}{l}\begin{array}{l}\text { Domain } \\
\text { terhadap }\end{array} \\
\text { Kematian pada }\end{array} \begin{array}{r}\text { Perawat } \\
\text { Persiapan }\end{array}$ & $\begin{array}{l}\text { Sangat } \\
\text { Setuju }\end{array}$ & Setuju & $\begin{array}{l}\text { Ragu- } \\
\text { Ragu }\end{array}$ & $\begin{array}{c}\text { Tidak } \\
\text { Setuju }\end{array}$ & $\begin{array}{c}\text { Sangat } \\
\text { Tidak } \\
\text { Setuju }\end{array}$ \\
\hline P21 & $\begin{array}{l}\text { Pasien menjelang ajal lebih } \\
\text { baik apabila mampu } \\
\text { mengungkapkan perasaannya }\end{array}$ & $\begin{array}{c}43 \\
(29,7 \%)\end{array}$ & $\begin{array}{c}89 \\
(61,4 \%)\end{array}$ & $\begin{array}{c}10 \\
(6,9 \%)\end{array}$ & $\begin{array}{c}3 \\
(2,1 \%)\end{array}$ & $\begin{array}{c}0 \\
(0 \%)\end{array}$ \\
\hline $\mathrm{P} 23$ & $\begin{array}{l}\text { Perawat seharusnya ijin kepada } \\
\text { pasien menjelang ajal untuk } \\
\text { mengunjungi dengan waktu } \\
\text { yang fleksibel }\end{array}$ & $\begin{array}{c}11 \\
(7,6 \%)\end{array}$ & $\begin{array}{c}99 \\
(68,3 \%)\end{array}$ & $\begin{array}{c}15 \\
(10,3 \%)\end{array}$ & $\begin{array}{c}19 \\
(13,1 \%)\end{array}$ & $\begin{array}{c}1 \\
(0.7 \%)\end{array}$ \\
\hline $\mathrm{P} 25$ & $\begin{array}{l}\text { Ketergantungan terhadap obat } \\
\text { pereda nyeri tidak seharusnya } \\
\text { menjadi pokok pembahasan } \\
\text { ketika berkkomunikasi dengan } \\
\text { pasien menjelang ajal }\end{array}$ & $\begin{array}{c}7 \\
(4,8 \%)\end{array}$ & $\begin{array}{c}84 \\
(57,9 \%)\end{array}$ & $\begin{array}{c}26 \\
(17,9 \%)\end{array}$ & $\begin{array}{c}24 \\
(16,6 \%)\end{array}$ & $\begin{array}{c}4 \\
(2,8 \%)\end{array}$ \\
\hline P26 & $\begin{array}{l}\text { Saya akan merasa tidak } \\
\text { nyaman jika saya memasuki } \\
\text { ruangan pasien dengan pasien } \\
\text { terminal dan mendapati pasien } \\
\text { tersebut menangis }\end{array}$ & $\begin{array}{c}6 \\
(4,1 \%)\end{array}$ & $\begin{array}{c}28 \\
(19,3 \%)\end{array}$ & $\begin{array}{c}19 \\
(13,1 \%)\end{array}$ & $\begin{array}{c}77 \\
(53,1 \%)\end{array}$ & $\begin{array}{c}15 \\
(10,3 \%)\end{array}$ \\
\hline $\mathrm{P} 27$ & $\begin{array}{l}\text { Pasien menjelang ajal harus } \\
\text { diberikan informasi yang } \\
\text { sebenarnya terkait kondisinya }\end{array}$ & $\begin{array}{c}33 \\
(22,8 \%)\end{array}$ & $\begin{array}{c}86 \\
(59,3 \%)\end{array}$ & $\begin{array}{c}12 \\
(8,3 \%)\end{array}$ & $\begin{array}{c}14 \\
(9,7 \%)\end{array}$ & $\begin{array}{c}0 \\
(0 \%)\end{array}$ \\
\hline P30 & $\begin{array}{l}\text { Perawat dimungkinkan } \\
\text { membantu pasien dalam } \\
\text { menyiapkan kematian pasien }\end{array}$ & $\begin{array}{c}36 \\
(24,8 \%)\end{array}$ & $\begin{array}{c}102 \\
(70,3 \%)\end{array}$ & $\begin{array}{c}5 \\
(3,4 \%)\end{array}$ & $\begin{array}{c}2 \\
(1,4 \%)\end{array}$ & $\begin{array}{c}0 \\
(0 \%)\end{array}$ \\
\hline
\end{tabular}

Tabel 5. menunjukkan domain pernyataan yang memiliki sikap positif tertinggi adalah perawat setuju bahwa perawat dimungkinkan membantu pasien dalam menyiapkan kematian pasien sebanyak 102 orang (70,3\%), sedangkan pernyataan yang memiliki sikap negatif tertinggi yaitu $82(56,6 \%)$ perawat setuju mengalihkan pembicaraan menuju hal yang menyenangkan adalah pilihan terbaik bila pasien bertanya tentang kematian.

Tabel 6. Distribusi Frekuensi Jawaban Pernyataan tentang Domain Sikap Perawat terhadap Persiapan Kematian pada Keluarga Pasien Kanker Stadium Lanjut $(n=145)$

\begin{tabular}{|c|c|c|c|c|c|c|}
\hline $\begin{array}{l}\text { No. } \\
\text { Item }\end{array}$ & $\begin{array}{llr}\begin{array}{l}\text { Domain } \\
\text { terhadap }\end{array} & \text { Sikap } & \begin{array}{r}\text { Perawat } \\
\text { Persiapan }\end{array} \\
\text { Kematian } & \text { pada } & \text { Keluarga } \\
\text { Pasien } & & \end{array}$ & $\begin{array}{l}\text { Sangat } \\
\text { Setuju }\end{array}$ & Setuju & $\begin{array}{l}\text { Ragu- } \\
\text { Ragu }\end{array}$ & $\begin{array}{c}\text { Tidak } \\
\text { Setuju }\end{array}$ & $\begin{array}{l}\text { Sangat } \\
\text { Tidak } \\
\text { Setuju }\end{array}$ \\
\hline $\mathrm{P} 4$ & $\begin{array}{l}\text { Merawat keluarga pasien } \\
\text { seharusnya terus menerus } \\
\text { sampai periode berduka dan } \\
\text { berkabung }\end{array}$ & $\begin{array}{c}49 \\
(33,8 \%)\end{array}$ & $\begin{array}{c}64 \\
(44,1 \%)\end{array}$ & $\begin{array}{c}19 \\
(13,1 \%)\end{array}$ & $\begin{array}{c}11 \\
(7,6 \%)\end{array}$ & $\begin{array}{c}2 \\
(1,4 \%)\end{array}$ \\
\hline
\end{tabular}




\begin{tabular}{|c|c|c|c|c|c|c|}
\hline $\begin{array}{l}\text { No. } \\
\text { Item }\end{array}$ & $\begin{array}{llr}\begin{array}{l}\text { Domain } \\
\text { terhadap }\end{array} & \text { Sikap } & \begin{array}{r}\text { Perawat } \\
\text { Persiapan }\end{array} \\
\text { Kematian } & \text { pada } & \text { Keluarga } \\
\text { Pasien } & & \end{array}$ & $\begin{array}{l}\text { Sangat } \\
\text { Setuju }\end{array}$ & Setuju & $\begin{array}{l}\text { Ragu- } \\
\text { Ragu }\end{array}$ & $\begin{array}{c}\text { Tidak } \\
\text { Setuju }\end{array}$ & $\begin{array}{c}\text { Sangat } \\
\text { Tidak } \\
\text { Setuju }\end{array}$ \\
\hline P9 & $\begin{array}{l}\text { Menciptakan hubungan yang } \\
\text { terbuka dengan keluarga pasien } \\
\text { yang menjelang ajal merupakan } \\
\text { sesuatu hal yang sulit }\end{array}$ & $\begin{array}{c}2 \\
(1,4 \%)\end{array}$ & $\begin{array}{c}52 \\
(35,9 \%)\end{array}$ & $\begin{array}{c}21 \\
(14,5 \%)\end{array}$ & $\begin{array}{c}67 \\
(46,2 \%)\end{array}$ & $\begin{array}{c}3 \\
(2,1 \%)\end{array}$ \\
\hline P12 & $\begin{array}{l}\text { Keluarga seharusnya terlibat } \\
\text { dalam perawatan pasien } \\
\text { menjelang ajal }\end{array}$ & $\begin{array}{c}81 \\
(55,9 \%)\end{array}$ & $\begin{array}{c}54 \\
(37,2 \%)\end{array}$ & $\begin{array}{c}3 \\
(2,1 \%)\end{array}$ & $\begin{array}{c}2 \\
(2,1 \%)\end{array}$ & $\begin{array}{c}4 \\
(2,8 \%)\end{array}$ \\
\hline P16 & $\begin{array}{l}\text { Keluarga membutuhkan } \\
\text { dukungan emosional untuk } \\
\text { menerima perubahan perilaku } \\
\text { pasien menjelang ajal }\end{array}$ & $\begin{array}{c}50 \\
(34,5 \%)\end{array}$ & $\begin{array}{c}86 \\
(59,3 \%)\end{array}$ & $\begin{array}{c}3 \\
(2,1 \%)\end{array}$ & $\begin{array}{c}5 \\
(3,4 \%)\end{array}$ & $\begin{array}{c}1 \\
(0,7 \%)\end{array}$ \\
\hline P18 & $\begin{array}{l}\text { Keluarga } \text { seharusnya berfokus } \\
\text { pada kenangan yang } \\
\text { terbaik/terindah dari pasien } \\
\text { yang menjalang ajal }\end{array}$ & $\begin{array}{c}19 \\
(13,1 \%)\end{array}$ & $\begin{array}{c}87 \\
(60,0 \%)\end{array}$ & $\begin{array}{c}19 \\
(13.1 \%)\end{array}$ & $\begin{array}{c}18 \\
(12,4 \%)\end{array}$ & $\begin{array}{c}2 \\
(1,4 \%)\end{array}$ \\
\hline $\mathrm{P} 20$ & $\begin{array}{l}\text { Keluarga seharusnya menjaga } \\
\text { lingkungan senormal mungkin } \\
\text { pada anggota keluarga inti } \\
\text { pasien menjelang ajal }\end{array}$ & $\begin{array}{c}31 \\
(21,4 \%)\end{array}$ & $\begin{array}{c}98 \\
(67,6 \%)\end{array}$ & $\begin{array}{c}14 \\
(9,7 \%)\end{array}$ & $\begin{array}{c}2 \\
(1,4 \%)\end{array}$ & $\begin{array}{c}0 \\
(0 \%)\end{array}$ \\
\hline P22 & $\begin{array}{lrr}\text { Proses perawatan } & \text { harus } \\
\text { mencakup keluarga } & \text { dengan } \\
\text { pasien menjelang ajal } & \end{array}$ & $\begin{array}{c}55 \\
(37,9 \%)\end{array}$ & $\begin{array}{c}83 \\
(57,2 \%)\end{array}$ & $\begin{array}{c}2 \\
(1,4 \%)\end{array}$ & $\begin{array}{c}3 \\
(2,1 \%)\end{array}$ & $\begin{array}{c}2 \\
(1,4 \%)\end{array}$ \\
\hline $\mathrm{P} 24$ & $\begin{array}{l}\text { Pasien menjelang ajal dan } \\
\text { keluarga seharusnya menjadi } \\
\text { pengambil keputusan utama }\end{array}$ & $\begin{array}{c}38 \\
(26,2 \%)\end{array}$ & $\begin{array}{c}90 \\
(62,1 \%)\end{array}$ & $\begin{array}{c}8 \\
(5,5 \%)\end{array}$ & $\begin{array}{c}9 \\
(6,2 \%)\end{array}$ & $\begin{array}{c}0 \\
(0 \%)\end{array}$ \\
\hline P28 & $\begin{array}{l}\text { Pendidikan terhadap keluarga } \\
\text { terkait kematian dan proses } \\
\text { kematian bukan tanggung } \\
\text { jawab dari perawat }\end{array}$ & $\begin{array}{c}3 \\
(2,1 \%)\end{array}$ & $\begin{array}{c}20 \\
(13,8 \%)\end{array}$ & $\begin{array}{c}10 \\
(6,9 \%)\end{array}$ & $\begin{array}{c}81 \\
(55,9 \%)\end{array}$ & $\begin{array}{c}31 \\
(21,4 \%)\end{array}$ \\
\hline P29 & $\begin{array}{l}\text { Anggota keluarga yang tinggal } \\
\text { dekat dengan pasien menjelang } \\
\text { ajal sering mengganggu } \\
\text { pekerjaannya dengan pasien }\end{array}$ & $\begin{array}{c}1 \\
(0,7 \%)\end{array}$ & $\begin{array}{c}17 \\
(11,7 \%)\end{array}$ & $\begin{array}{c}26 \\
(17,9 \%)\end{array}$ & $\begin{array}{c}86 \\
(59,3 \%)\end{array}$ & $\begin{array}{c}15 \\
(10,3 \%)\end{array}$ \\
\hline
\end{tabular}

Tabel 6 menunjukkan pernyataan yang memiliki sikap positif tertinggi adalah sebanyak 98 perawat $(67,6 \%)$ setuju bahwa keluarga seharusnya menjaga lingkungan senormal mungkin pada anggota keluarga inti pasien menjelang ajal, sedangkan pernyataan yang memiliki sikap negatif tertinggi yaitu sebanyak 52 perawat $(35,9 \%)$ setuju bahwa menciptakan hubungan yang terbuka dengan keluarga pasien menjelang ajal merupakan sesuatu hal yang sulit. 


\section{B. Pembahasan}

Hasil penelitian menunjukkan bahwa usia responden dikategorikan ke dalam usia dewasa awal dan produktif (Departemen Kesehatan Republik Indonesia, 2013). Individu mengalami perkembangan kedewasaan yang mencakup peningkatan dalam karakter, sikap dan juga lebih berperan aktif pada pekerjaan dan kehidupan sosialnya. Individu cenderung akan memperhatikan ide- ide, keinginan untuk berbagi pengetahuan, dan meningkatkan kreativitas (Perry \& Potter, 2010). Perawat yang berusia lebih muda cenderung memiliki tingkat ketakutan yang lebih tinggi dalam menghadapi kematian pada pasien terminal dibandingkan dengan perawat yang memiliki usia lebih tua. Perawat muda memiliki ntensitas yang kurang dalam menemukan dan merawat pasien yang meninggal dunia. Berbeda dengan perawat yang lebih tua, mereka memiliki penerimaan akan kematian pasien yang lebih besar dan cenderung memandang kematian sebagai hal yang netral. Mereka tidak mengharapkan namun juga tidak takut akan sebuah kematian. Mereka menganggap kematian sebagai kebebasan pasien dari penderitaan dan rasa sakit yang dideritanya selama ini (Lange, Thom, \& Kline, 2008).

Pada penelitian ini ditemukan bahwa responden didominasi oleh jenis kelamin perempuan. Perempuan memiliki sifat pengasuh yang bermula dari naluri keibuan (mother instinct) (Friedman, Howard, \& Scustack, 2012). Sifat tersebut diperlukan dalam melakukan tugas keperawatan yang mencakup ketelitian, ketelatenan serta kesabaran. Perempuan juga memiliki kecenderungan untuk menunjukkan kecemasan akan kematian pada pasien yang berada pada tahap akhir kehidupan. Perempuan akan lebih terbuka terhadap pikiran dan perasaan yang berhubungan dengan kematian sedangkan laki-laki akan lebih cenderung untuk menyimpan perasaan dan pemikirannya. Hal ini dihubungkan dengan rasa empati yang dimiliki oleh perempuan terhadap pasien yang sedang berada pada kondisi terminal dan berduka. Perempuan akan lebih menunjukkan keinginannya untuk membantu pasien maupun keluarga pasien dalam mengatasi permasalahan terkait kondisi pada akhir kehidupan (Hasheesh, et al., 2013).

Hasil penelitian menunjukkan bahwa mayoritas perawat berpendidikan terakhir DIII Keperawatan. Pihak rumah sakit telah berupaya dalam memfasilitasi 
perawat melalui tugas belajar yang bekerjasama dengan instansi pendidikan untuk meningkatkan tingkat pendidikan formalnya. Pendidikan formal dapat meningkatkan kemampuan intelektual yang akan berdampak pada peningkatan pengetahuan, sikap serta kompetensi pada bidang tertentu (Gibson, Ivancevich, \& Donnelly, 2010). Pendidikan yang dicapai seseorang diharapkan menjadi faktor determinan produktifitas antara lain knowledge, skills, abilities, attitude, dan behavior yang cukup dalam menjalankan aktifitas pekerjaanya (Azwar, 2011).

Hasil penelitian menunjukkan bahwa mayoritas perawat telah bekerja dibangsal kanker selama 0 hingga 5 tahun. Masa kerja yang lama, membuat perawat lebih banyak memiliki pengalaman dalam menemui kasus dengan kondisi pasien terminal pada praktik sehari-harinya. Pengalaman membuat perawat lebih nyaman menjalankan pekerjaannya, meningkatkan pengetahuan, konsep diri, pemecahan masalah serta keterampilan perawat dalam memberikan pelayanan kepada keluarga dan pasien menjelang akhir kehidupan (Hasheesh, et al., 2013).

Hasil penelitian menunjukkan bahwa mayoritas perawat telah ikut serta dalam seminar atau pelatihan perawatan paliatif. Penting bagi perawat guna memperoleh informasi terbaru dalam penatalaksanaan perawatan akhir kehidupan. Keikutsertaan dalam pelatihan akan berdampak pada sikap positif perawat terhadap pemberian perawatan menjelang kematian bagi pasien dan keluarga pasien (Agustinus \& Chan, 2013).

Terbentuknya sikap positif dari perawat tersebut dapat dipengaruhi oleh interaksi yang terjadi antar sesama perawat yang bekerja. Hal tersebut menyebabkan terjadinya pertukaran informasi mengenai hal-hal yang berhubungan dengan pelaksanaan asuhan keperawatan. Perawat akan memperhatikan kebutuhan pasien serta mengajak perawat lain untuk mengerjakan dan mendiskusikan suatu masalah keperawatan terkait dengan kondisi pasien terminal (Kiran, Sri, \& Dewi, 2017).

Hasil penelitian ini juga diperkuat dengan penelitian Utami (2009) yang mengungkapkan bahwa pengalaman kerja tanpa melihat waktu lama bekerja dapat mempengaruhi sikap perawat. Pengalaman pribadi dalam perawatan akhir kehidupan membuat perawat semakin memiliki keberanian dan kemudahan dalam 
mengekspresikan pembahasan mengenai kematian. Hal ini tentunya akan meningkatkan skill perawat dalam berinteraksi dengan keluarga maupun pasien yang berada pada tahap akhir kehidupan (Lancaster, et al., 2017).

Sikap perawat yang positif terhadap persiapan kematian juga didukung oleh keikutsertaan perawat dalam pendidikan non formal berupa seminar maupun pelatihan perawatan akhir kehidupan. Perawat akan lebih memahami tentang perawatan akhir kehidupan, manajemen nyeri dan gejala, tujuan dari perawatan akhir kehidupan dan perencanaan perawatan lanjutan. Selain itu melalui pelatihan juga, perawat akan belajar mengintrepetasikan kembali, merefleksikan pengalaman perawat dan mengkomunikasikan perasaannya untuk membangun respect dan empati yang akan mendorong terbentuknya sikap yang positif (Kassa, Murugan, Zewdu, Hailu, \& Woldeyohannes, 2014). Sikap positif perawat juga dapat dibentuk oleh pendidikan formal yang didapatkan ketika perawat menempuh pendidikan saat perkuliahan. Pendidikan formal tersebut di dapatkan dalam bentuk teori tentang perawatan pasien menjelang ajal dan secara tidak langsung prakteknya didapatkan saat mengelola pasien di rumah sakit.

Kurangnya pelatihan dan pendidikan yang tepat tentang perawatan akhir kehidupan dapat menimbulkan sikap negatif pada perawat yang tentunya akan mempengaruhi hasil dari perawatan (Khader, Jarrah, \& Alasad, 2010). Perawat dididik untuk merawat pasien dalam berbagai tahap penyakit namun peran perawat tidak ditekankan dengan baik dalam memberikan perawatan akhir kehidupan pada pasien maupun keluarga. Hasil studi menyebutkan bahwa kurangnya pelatihan akan membuat perawat merasa tidak peduli, takut, cemas, dan kurang percaya diri dalam setiap pemberian asuhan keperawatan yang dapat menurunkan kualitas pelayanan menjelang ajal pada pasien dan keluarga (Grubb \& Arthur, 2016). Namun apabila perawat menerima pendidikan dan pelatihan yang sesuai untuk perawatan akhir kehidupan, tentunya sikap positif akan berkembang pada diri perawat. Oleh karena itu, pentingnya kebutuhan integrasi antara pendidikan formal dengan non formal tentang perawatan menjelang ajal. 
Hasil penelitian menunjukkan bahwa perawat memiliki sikap yang positif terhadap persiapan kematian pada pasien. Mayoritas perawat menganggap sangat dimungkinkan perawat membantu pasien dalam menyiapkan kematian yang damai dan berkualitas. Hal ini menunjukkan bahwa perawat memiliki kemauan yang kuat dalam merawat pasien yang mendekati ajal. Perawat akan rela berupaya untuk memahami penderitaan pasien yang berada dalam tahap akhir kehidupan dan berusaha menjadi perawat yang dapat membantu sebaik mungkin dalam memberikan perawatan akhir kehidupan yang berkualitas kepada pasien (Kondo \& Nagata, 2015). Perawat menyadari peran dan tanggung jawabnya dalam memberikan asuhan keperawatan berupa persiapan kematian kepada pasien yang berada pada tahap akhir kehidupan. Perawat juga mengganggap pengalaman merawat pasien menjelang ajal sebagai hal yang berkesan. Pengalaman yang meninggalkan kesan kuat akan lebih mudah dalam membentuk sebuah sikap karena melibatkan faktor emosional maupun perasaan dalam pengalaman pribadi yang dianggap mendalam, berharga, dan unik tersebut (Azwar, 2011). Sikap perawat yang positif akan membantu perawat untuk memberikan dukungan secara fisik, psikologis, sosial, dan spiritual secara optimal yang diketahui efektif dalam memberikan dampak positif pada pasien kanker untuk meninggal dengan baik (National Institute for Clinical Excellent, 2004). Adapun dalam hal sikap perawat terhadap berkomunikasi dengan pasien dan keluarga mereka dalam membahas tentang masalah akhir kehidupan masih perlu ditingkatkan. Hal ini dapat disebabkan karena membicarakan tentang kematian yang masih dianggap tabu oleh masyarakat sehingga menjadi problematika bagi perawat. Adanya kesulitan komunikasi yang efektif tentang perihal persiapan kematian menjadi hambatan perawat untuk berinteraksi dengan keluarga maupun pasien. Komunikasi ini bertujuan untuk meningkatkan kualitas hidup dan mempersiapkan kematian yang damai serta berkualitas bagi pasien kanker stadium terminal. Komunikasi terapeutik dalam mempersiapkan kematian dapat menjadi wahana bagi perawat untuk mendalami hal yang diharapkan pasien tentang kematian yang baik serta memfasilitasi kesiapan pasien dalam penerimaan kondisi menjelang ajal (National Institute for Clinical Excellent, 2004). 
Hasil penelitian ini juga menunjukkan bahwa mayoritas perawat memiliki sikap yang positif terhadap persiapan kematian pada keluarga pasien kanker stadium lanjut. Perawat memiliki sikap yang sejalan dengan pengertian dari perawatan akhir kehidupan yang mencakup perawatan baik untuk pasien maupun keluarga pasien (The National Council for Palliative Care, 2006). Keterlibatan keluarga dalam perawatan menjelang kematian akan meningkatkan kualitas hidup pasien. Sikap perawat yang positif akan mendukung keterlibatan keluarga dalam membantu menerapkan rencana perawatan, merawat anggota keluarga yang mendekati ajal, serta membantu membuat keputusan yang tentunya selaras dengan keingingan pasien di akhir kehidupannya (Sudore, Casarett, Smith, Richardson, \& Ersek, 2014). Perawat juga memiliki kecenderungan yang positif terkait dengan standar perawatan menjelang kematian yang diberikan untuk keluarga pasien tentang pemberian dukungan kepada keluarga. Dukungan kepada keluarga dapat diberikan melalui bentuk komunikasi maupun memfasilitasi keluarga untuk bersama pasien pada saat pasien menjelang kematiannya. Terutama apabila kematian terjadi secara mendadak tentunya perawat akan memberikan dukungan secara fisik maupun emosional yang lebih terhadap keluarga. Hal tersebut memberikan pengaruh yang positif pada hasil perawatan maupun persiapan kematian pada pasien dan keluarga pasien kanker (Donovan \& Browne, 2013). Adapun sikap perawat terhadap keterbukaan pada keluarga pasien dalam mepersiapakan kematian pasien kanker stadium lanjut masih perlu ditingkatkan. Hal ini sejalan dengan penelitian Mak, Chung, Chiang, \& Chui (2013) yang mengungkapkan bahwa perawat dapat merasakan ketidakmampuan dan mengalami tekanan yang berat dalam memberikan perawatan pada pasien menjelang kematian khususnya menghadapi resiko keluarga yang berduka disfungsional. Adapun faktor budaya masyarakat juga masih menjadi kendala. Perawat perlu membekali diri dalam mempersiapkan keluarga menghadapi kematian pasien dengan menunjukkan sikap terbuka pada keluarga.

\section{KESIMPULAN}

Hasil penelitian menunjukkan bahwa lebih dari separuh responden perawat $(52,4 \%)$ memiliki sikap yang positif terhadap persiapan kematian pasien kanker tahap terminal. Hasil analisis dari dua domain yaitu sebanyak 53,8\% perawat 
memiliki sikap positif terhadap persiapan kematian pada pasien dan sebanyak $57,2 \%$ perawat memiliki sikap positif terhadap persiapan kematian pada keluarga pasien. Berdasarkan hasil tersebut, perawat diharapkan dapat lebih meningkatkan sikap positif khususnya terhadap komunikasi yang terbuka pada pasien dan keluarga pasien dalam membahas masalah akhir kehidupan demi mencapai peningkatan kualitas hidup dan kematian yang baik.

\section{DAFTAR PUSTAKA}

A'la, M. Z. (2016). The frommelt attitudes toward care of the dying care form $b$ (FATCOD-B) versi bahasa indonesia: pengukuran validitas pada mahasiswa keperawatan menggunakan analisis faktor. NurseLine Journal, 1(1), 73-82.

A'la, M. Z., Setioputro, B., \& Kurniawan, D. E. (2018). Nursing student's attitudes towards caring for dying patients. Nurse Media Journal of Nursing, 8(1), 2534. https://doi.org/10.14710/nmjn.v8i1.17270.

Agustinus, S., \& Chan, S. W. C. (2013). Factors affecting the attitudes of nurses towards palliative care in the acute and long term care setting: a systematic review. JBI, 11 (1), 1-69. https://doi.org/10.11124/jbisrir-2013-604.

Atika, D.D., Fitriyah., \& Indriani. (2008). Penanganan masalah sosial dan psikologis pasien kanker stadium lanjut dalam perawatan paliatif. Journal Of Cancer, 1, 30-34. https://doi.org/10.33371/ijoc.v2i1.36.

Azwar, S. (2011). Sikap manusia, teori, dan pengukurannya. Yogyakarta: Pustaka Pelajar.

Departemen Kesehatan, RI. (2007). Keputusan Menteri Kesehatan RI Nomor 812 Tahun 2007 tentang kebijakan perawatan paliatif. Jakarta: Departemen Kesehatan RI.

Departemen Kesehatan Republik Indonesia. (2013). Kesehatan dasar. Jakarta.

Donovan, H., \& Browne, M. (2013). Introduction quality standards for end-of-life care in hospitals. Ireland: Hospice Friendly Hospitals.

Fitri, E. Y., Natosba, J., \& Andhini, D. (2017). Gambaran pengetahuan, sikap dan tindakan perawatan paliatif perawat. Seminar dan Workshop Nasional Keperawatan "Implikasi Perawatan Paliatif Pada Bidang Kesehatan" Dalam, 3(1), 218-222.

Friedman, Howard, \& Scustack, M. (2012). Kepribadian teori klasik dan riset modern. Jakarta: Erlangga.

Gibson, J. L., Ivancevich, J. M., \& Donnelly, J. H. (2010). Organisasi : perilaku, struktur, proses. Jakarta: Binarupa Aksara.

Grubb, C., \& Arthur, A. (2016). Student nurses ' experience of and attitudes towards care of the dying : A cross-sectional study. Palliative Madicine, 30(1), 
83-88. https://doi.org/10.1177/0269216315616762.

Hasheesh, M. O. A., AboZeid, S. A.-S., El-Said, S. G., \& Alhujaili, A. D. (2013). Nurses' characteristics and their attitudes toward death and caring for dying patients in a public hospital in Jordan. Health Science Journal, 7(4), 384-394.

Indonesia Ministry of Health (Depkes RI). (2016). INFODATIN: Breast Cancer Situation Report.

Kassa, H., Murugan, R., Zewdu, F., Hailu, M., \& Woldeyohannes, D. (2014). Assessment of knowledge, attitude and practice and associated factors towards palliative care among nurses working in selected hospitals , Addis Ababa, Ethiopia. BMC Palliative Care, 13(6), 1-11. https://doi.org/10.1186/1472684X-13-6.

Kementrian Kesehatan Republik Indonesia. (2015). Pusat data dan informasi : situasi penyakit kanker. Kementerian Kesehatan RI.

Kementrian Kesehatan Republik Indonesia. (2018). Riset kesehatan dasar 2018. Kementrian Kesehatan Republik Indonesia.

Khader, K. A., Jarrah, S. S., \& Alasad, J. (2010). Influence of nurses' characteristics and education on their attitudes towards death and dying: a review of literature. International Journal of Nursing and Midwifery, 2(1), 1-9. Retrieved from http://www.academicjournals.org/ijnm.

Kiran, Y., Sri, U., \& Dewi, P. (2017). Pengetahuan dan sikap perawat dalam memenuhi kebutuhan psikologis dan spiritual klien terminal. Jurnal Pendidikan Keperawatan Indonesia, 3(2), 182-189. https://doi.org/10.17509/jpki.v3i2.9425.

Kondo, M., \& Nagata, H. (2015). Nurses' involvement in patients' dying and death : scale development and validation. Journal of Death and Dying, 70(3), 278300. https://doi.org/10.1177/0030222815568959.

Kübler-Ross, E. (2009). On death and dying: what the dying have to teach doctors, nurses, clergy, and their own families. The 40th Anniversary Edition. London: Routledge Taylor \& Francis Group.

Lancaster, R. J., Kautzmann, C., Micheal, J. C. J., Chandrasekaran, L., Jambunathan, J., \& Chapin, T. M. (2017). Attitudes of nurses towards care of the dying patient in India. International Journal of Palliative Nursing, 23(11), 558-566. https://doi.org/10.12968/ijpn.2017.23.11.558.

Lange, M., Thom, B., \& Kline, N. E. (2008). Assessing nurses' attitudes toward death and caring for dying patients in a comprehensive cancer center. Oncology Nursing Forum, 35(6), 955-960. https://doi.org/10.1188/08.ONF.955-959.

Mak, Y.W., Chung, V., Chiang, L., \& Chui, W.T. (2013). Experiences and perceptions of nurses caring for dying patients and families in the acute medical admission setting. International Journal of Palliative Nursing, 19(9), 423-432. https://doi.org/10.12968/ijpn.2013.19.9.423. 
Miyashita, M., Kawakami, S., Kato, D., Yamashita, H., Igaki, H., Nakano, K., ... Nakagawa, K. (2015). The importance of good death components among cancer patients, the general population, oncologists, and oncology nurses in Japan : patients prefer "fighting against cancer." Support Care Cancer, 23, 103-110. https://doi.org/10.1007/s00520-014-2323-z.

National Institute for Clinical Excellent. (2004). Improving supportive and palliative care for adults with cancer. London: National Institute for Clinical Excellent.

Perry, A. G., \& Potter, P. A. (2010). Fundamental of nursing: concept, process, and practice. (7th ed.). Jakarta: EGC.

Sudore, R. L., Casarett, D., Smith, D., Richardson, D. M., \& Ersek, M. (2014). Family involvement at the end-of-life and receipt of quality care. Journal of Pain and Symptom Management, 48(6), 1108-1116. https://doi.org/10.1016/j.jpainsymman.2014.04.001.

Tayeb, M. A., Al-Zamel, E., Fareed, M. M., \& Abouellail, H. A. (2010). A "good death": perspectives of muslim patients and health care providers. Annals of Saudi Medicine, 30(3), 215-221. https://doi.org/10.4103/0256-4947.62836.

The International Agency for Research on Cancer. (2018). Latest global cancer data. Retrieved from https://gco.iarc.fr/today/data/factsheets/cancers/39-Allcancers-fact-sheet.pdf.

The National Council for Palliative Care. (2006). End of life care strategy. London.

Utami, Y. W. (2009). Hubungan antara pengetahuan dengan sikap perawat dalam pemenuhan kebutuhan spiritual pasien di RSUD Sukoharjo. Berita Ilmu Keperawatan, 2(2), 69-74.

Vergo, M. T., Whyman, J., Li, Z., Kestel, J., James, S. L., Rector, C., \& Salsman, J. M. (2016). Assessing preparatory grief in advanced cancer patients as an independent predictor of distress in an american population. Journal of Palliative Medicine, 20(1), 1-5. https://doi.org/10.1089/jpm.2016.0136.

Wahyuni, D., Huda, N., \& Utami, G. T. (2015). Studi fenomenologi: pengalaman pasien kanker stadium lanjut yang menjalani kemoterapi. JOM, 2(2), 10411047.

Zheng, R., Guo, Q., Dong, F., \& Owens, R. G. (2015). Chinese oncology nurses' experience on caring for dying patients who are on their final days: A qualitative study. International Journal of Nursing Studies, 52(1), 288-296. https://doi.org/10.1016/j.ijnurstu.2014.09.009. 